\title{
Upaya Meningkatkan Minat Nasabah Produk BNI Griya Pada Bank Negara Indonesia (BNI) Cabang Sintang
}

\author{
Paulus \\ Fakultas Ilmu Sosial dan Ilmu Politik Universitas Kapuas Sintang \\ Alamat : Jalan YC Oevang Oeray No 92 Sintang \\ Email : paulusssemari@yahoo.com
}

\begin{abstract}
ABSTRAK : BNI Griya merupakan salah satu produk BNI Cabang Sintang yang merupakan produk kredit. Produk BNI Griya disiapkan bagi nasabah yang memiliki keinginan untuk mendapatkan fasilitas pinjaman yang bertujuan untuk membeli rumah tempat tinggal, renovasi, dan pembangunan rumah baru. Selain itu produk BNI Griya juga dapat dipergunakan untuk keperluan kredit multi guna bagi nasabah yang memerlukan kredit untuk berbagai keperluan.Produk BNI Griya khusus untuk nasabah yang berprofesi sebagai pegawai baik pegawai Negeri Sipil maupun pegawai swasta. Upaya untuk menarik minat para nasabah maka manajemen BNI melakukan promosi, yaitu dengan cara mendatangi instansi-istansi pemerintah maupun swasta yang dilakukan oleh staf marketing (pemasaran). Promosi dilakukan dengan bantuan media promosi berupa brosur yang berisikan informasi mengenai manfaat dan keunggulan produk BNI Griya.Suku bunga produk BNI Griya bervariasi sesuai dengan sistem yang diterapkan.Suku bunga dengan menggunakan sistem flat rate (sistem bunga tetap) danfloating rate (sistem bunga mengambang). Sistem flat rate tingkat suku bunganya dibawah $12 \%$ pertahun atau dibawah $1 \%$ perbulan.
\end{abstract}

Kata Kunci : Upaya, Meningkatkan, Minat, Nasabah

\section{PENDAHULUAN}

Lembaga perbankan merupakan salah satu dari sekian banyak lembaga keuangan yang ada di tanah air sebagai penggerak perekonomian nasional. Melalui lembaga perbankan pemerintah dapat mengatur permintaan dan penawaran uang dengan mengeluarkan kebijakan moneter. Kebijakan tersebut dilakukan untuk mengatur dan mengendalikan jumlah uang beredar sehingga kestabilan dan pertumbuhan ekonomi dapat tercapai yang pada sasaran akhirnya untuk peningkatan pendapatan perkapita masyarakat sehingga kesejahteraan dapat diwujudkan sesuai yang dicita-cita bangsa Indonesia seperti yang tercantum pada pembukaan UUD 1945.

Lembaga perbankan sebagai lembaga keuangan yang dominan pengaruhnya dibanding lembaga keuangan non bank di dalam sistem moneter telah ada sejak Indonesia merdeka bahkan sebelum kemerdekaan telah di dirikan oleh bangsa asing di Indonesia sebagai pengatur tatanan keuangan bagi sebuah negara dan masyarakat. Setelah kemerdekaan maka bank-bank asing telah diambil oleh bangsa indonesia sehingga menjadi milik bangsa Indonesia. Seiring jaman, peranan bank semakin besar peranannya bukan hanya sebagai lembaga tempat menyimpan uang saja.
Peranan perbankan bagi suatu negara pada dasarnya merupakan lembaga intermediasi yaitu menampung uang bagi pelaku ekonomi baik pengusaha maupun individu yang pada saat tertentu masih kelebihan uang untuk dibelanjakannya. Uang tersebut disimpan unit surplus tersebut dalam bentuk rekening tabungan nasabah di lembaga bank. Demikian pula sebaliknya unit yang memerlukan uang atau debitur dapat melakukan pengajuan pinjaman ke lembaga bank untuk mendapatkan sejumlah dana dalam rangka memenuhi likuiditasnya.

Selain sebagai fungsi utama melakukan jasa pelayanan tabungan dan kredit, lembaga perbankan juga melayani jasa-jasa perbankan lainnya seperti jasa pengiriman uang (transfer), penitipan barang-barang penting nasabah (safe deposit box), Letter of Credit (L/C), Inkaso, Kliring, penukaran uang asing dan berbagai jasa perbankan lainnya. Fungsi-fungsi bank tersebut pada setiap lembaga bank secara umum sama, hanya beberapa pelayanan tertentu yang tidak ada seperti penukaran valuta asing dan L/C.

Sebagai lembaga atau organisasi yang bergerak di bidang jasa keuangan, bank juga mencari profitabilitas untuk eksistensi serta kemajuan lembaga yang pada akhinya dapat 
memenuhi semua harapan dan keinginan stakeholder terkait. Lembaga perbankan memerlukan sumber daya berkualitas tinggi karena berkaitan dengan keuangan dan pelayanan kepada nasabah dan masyarakat pada umumnya.

Kompetensi para pegawai, dewan komisaris dan direksi bank menjadi kunci berkualitasnya lembaga perbankan. Setiap bagian tentunya memiliki tugas dan fungsinya masingmasing sesuai dengan peraturan internal perbankan. Dewan direksi dan komisaris bank merupakan pihak yang bertanggung jawab terhadap berbagai aspek bisnis perbankan termasuk di dalam strategi dalam penetapan produk yang dipasarkan. Sebagai mana fungsi lembaga bank yaitu sebagai tempat menyimpan uang bagi nasabah, tentu strategi produk menjadi perhatian penting untuk dirancang dan dipasarkan dengan kemampuan bersaing.Bank Negara Indonesia (BNI) merupakan salah satu bank konvensionalyang memberikan jasa perbankan dengan produk simpanan, pinjaman dan produk jasa bank lainnya. BNI tersebar di seluruh Indonesia termasuk di Kota Kabupaten Sintang yaitu BNI Cabang Sintang dengan beberapa kantor Cabang Pembantu dibeberapa wilayah di kota Sintang. BNI memiliki beberapa produk simpanan, dan pinjaman (kredit), salah satu produk pinjaman adalah BNI Griya, yaitu jenis produk pinjaman yang dikhususkan untuk nasabah yang memerlukan dana untuk Kredit Pemilikan Rumah (KPR), renovasi bangunan, serta untuk keperluan multi guna.

BNI Griya memiliki variasi tingkat suku bunga yaitu untuk $6,75 \%$ per tahun untuk 2 (dua) tahun pertama proses pengangsuran, kemudian 7,75 $\%$ per tahun untuk 2 tahun berikutnya, tahun-tahun pengangsuran selanjutnya berlaku sistem bunga mengambang (floating rate). Pemasaran produk BNI Griya menjadi perhatian khusus BNI disamping pemasaran produk-produk tabungan lainnya. Untuk dapat memperoleh debitur sesuai dengan yang ditargetkan, pihak bank BNI harus lebih fokus melihat segmentasi pasar, melakukan banyak promosi, dan mempermudah persyaratan perkreditan dengan batasan yang aman, serta memberikan tingkat suku bunga yang kompetitif.

Menurut Kasmir (2013 : 35), "kegiatan bank umum yaitu menghimpun dan menyalurkan dana. Dana yang dihimpun disimpan dalam bentuk produk simpanan, sedangkan penyaluran dana dalam bentuk kredit". Produk simpanan secara umum menurut kasmir $(2013: 35)$ terdiri dari : "1). Simpanan giro, 2). Simpanan tabungan, dan 3). Simpanan deposito. Sementara produk kredit secara umum dibedakan menjadi 6 (enam) kategori yaitu : 1). Kredit investasi, 2). Kredit modal kerja, 3). Kredit Perdagangan, 4). Kredit produktif, 5). Kredit Konsumtif, dan 6). Kredit Profesi”.

Setiap bank memiliki ciri khas nama produk tersendiri sesuai dengan tujuan dan keinginan bank masing-masing. Namun demikian fungsinya tetap mengacu kepada enam jenis kategori kredit yang diuraikan diatas. Berdasarkan data yang peneliti peroleh dari Bank BNI cabang Sintang, Bank BNI Cabang sintang memiliki 3 (tiga) nama produk kredit yaitu : 1). BNI Griya, 2). Kredit Usaha Rakyat (KUR), dan 3). Fleksi.

Minat Konsumen/nasabah terhadap produk dipengaruhi oleh berbagai faktor yang terkait dengan produk yang dipasarkan. Banyak sekali faktor yang mempengaruhi minat konsumen produk perbankan diantaranya adalah pengetahuan konsumen tentang manfaat produk, harga/balas jasa, kualitas pelayanan yang diberikan oleh pihak perbankan, dan kemampuan dari nasabah dalam memahami manfaat dari produk serta kemampuan finansialnya untuk membeli produk tersebut. Selain kemampuan membeli tentu nasabah harus memiliki modal yaitu berupa uang yang harus disimpan di bank sebagai tanda kepesertaan sebagai nasabah sehingga memiliki hak atas jasa-jasa lain yang disediakan perbankan.

Pengertian nasabah menurut UndangUndang Nomor 10 tahun 1998 "adalah pihak yang menggunakan jasa perbankan". Dengan demikian berarti nasabah merupakan konsumen atau pelanggan lembaga perbankan. Sementara minat adalah kecendrungan hati yang tinggi terhadap sesuatu atau disebut juga gairah dan keinginan. Oleh karena itu minat nasabah berarti keinginan nasabah akan suatu produk bank. Minat nasabah tentu sangat tergantung kepada faktor internal dan eksternal nasabah. Oleh karena itu lembaga perbankan harus memperhatikan keinginan nasabah sehingga produk yang dipasarkan dapat diminati oleh nasabah.

Untuk menumbuhkan minat masyarakat terhadap produk BNI, maka lembaga perbankan perlu memperhatikan beberapa aspek untuk diprogramkan di dalam upaya tersebut. Aspekaspek yang harus dianalisis adalah segmentasi pasar, promosi, Suku bunga, dan pelayanan.

\section{Segmentasi Pasar}

Segmentasi pasar merupakan bagianbagian di dalam suatu pasar ditinjau dari segi 
konsumen yang memiliki kebutuhan atau keinginan yang sama akan suatu produk yang dihasilkan oleh produsen. Suatu segmen juga dapat terjadi karena kondisi geografis, sosial budaya, pendidikan, agama dan kepercayaan, jenis kelamin, usia dan sebagainya.

Menurut Sunyoto (2014 : 45), bahwa segmentasi pasar adalah usaha untuk mengelompok-kelompokkan pasar dari pasar yang bersifat heterogen menjadi bagian-bagian pasar yang memiliki sifat homogen.Lebih lanjut menurut Kotler (Sunyoto (2014 : 45), segmentasi pasar dibedakan menjadi beberapa segmen yaitu : 1) Segmentasi Pasar Geografi; Segmentasi pasar geografi perlu membagi pasar ke dalam unit-unit geografi yang berbeda seperti negara, negara bagian, provinsi, kabupaten, kecamatan, kota, dan desa. 2) Segmentasi Pasar Demografi; Segmentasi pasar demografi merupakan pembagian pasar ke dalam kelompok-kelompok berdasarkan variabelvariabel demografi seperti usia, jenis kelamin, jumlah penduduk, jumlah keluarga, pendapatan, pekerjaan, jenjang pendidikan, dan kewarganegaraan. 3) Segmentasi Pasar Psikografi; Pada segmentasi pasar psikografi, analis pasar membagi para pembeli ke dalam kelompokkelompok yang berbeda-beda berdasarkan kelas sosial, gaya hidup, dan ciri-ciri kepribadian.

4) Segmentasi Pasar Behavioristik; Yaitu para konsumen dibagi ke dalam kelompok-kelompok berdasarkan pengetahuan, sikap, penggunaan atau tanggapan mereka terhadap sebuah produk.

Dengan mengetahui pembagian pasar tersebut pelaku pasar dalam hal ini pelaku bisnis perbankan harus dapat menentukan segmen yang mana yang cendrung memiliki minat terhadap produk khususnya produk BNI Griya sehingga fokus pemasaran produk dapat lebih terarah sehingga lembaga perbankan lebih dapat meningkatkan pengenalan produk kepada konsumen atau calon nasabah. Berdasarkan segmentasi pasar, pihak perbankan juga dapat mempelajari karateristik dari konsumen sehingga selanjutnya membuat rencana jangka pendek maupun jangka panjang berkaitan program pemasaran produk yang meliputi penentuan karakteristik produk, manfaat, penentuan tingkat suku bunga, limit flapon kredit, jangka waktu dan sebagainya.

Menurut Kotler dan Armstrong (2001 : 312-313), persyaratan agar segmentasi dapat dilakukan secara efektif, antara lain : 1) Dapat di ukur; Hal-hal yang harus dapat diukur dalam menentukan segmentasi ini adalah : besar, daya beli, dan profil segmen dapat diukur. 2) Dapat di akses; Segmentasi pasar dapat secara efektif dijangkau dan dilayani. 3) Substansial; Segmentasi pasar harus cukup besar atau menguntungkan untuk dilayani. Suatu segmen haruslah suatu grup homogeny terbesar yang layak disasar dengan suatu program pemasaran yang disesuaikan. 4) Dapat dibedakan; Suatu segmen secara konsep harus dapat dibedakan dan memberikan tanggapan yang berbeda terhadap elemen bauran pemasaran dan program memasaran yang berbeda. 5) Dapat ditindaklanjuti; Program yang efektif dapat di desain untuk menarik dan melayani segmen.

\section{Promosi}

Menurut Alma (2007:179) "promosi merupakan sejenis komunikasi yang memberikan penjelasan yang meyakinkan calon konsumen tentang barang dan jasa. Tujuan promosi adalah memperoleh perhatian, mendidik, mengingatkan, dan meyakinkan calon konsumen". Sementara menurut Kotler (2007 : 35) bahwa "promosi termasuk aktivitas atau kegiatan perusahaan untuk mengkomunikasikan jenis produknya kepada target pasar (masyarakat) (promotion includes all the activities the company undertakes to communicate anda promote its product the target market). Berkaitan dengan kegiatan produksi, produsen barang industri misalnya banyak menitik beratkan pada Personal Selling (sales) daripada periklanan, meskipun keduanya sering pula dilakukan bersamasama. Hal ini dilakukan karena menganggap secara geografis pemakai industri lebih memusat dan jauh lebih sedikit dari pada konsumen. Selain itu juga sifat teknis dari produksinya memungkinkan bagi produsen yang menggunakan salesman.Strategi promosi yang dilakukan oleh BNI, khususnya untuk produk BNI Griya adalah dengan melakukan pencetakan brosur-brosur yang berisikan karakteristik produk seperti fungsi produk, tingkat suku bunga, dan jangka waktu kredit. Selain itu promosi juga dilakukan dengan metode personal selling, yaitu promosi yang dilakukan staf marketing langsung menyampaikan kepada calon nasabah yang potensial. Staf marketing menjelaskan keunggulan produk-produk tersebut kepada calon nasabah. Selanjutnya dilakukan pula sistem Mouth to Mouth, yaitu penyampaian informasi produk dari nasabah ke calon nasabah sehingga informasi mengenai produk dapat tersebar luas ke masyarakat.

\section{Tingkat Suku Bunga}


Menurut Kasmir (2013 :114), bahwa bunga bank diartikan sebagai balas jasa yang diberikan oleh bank yang berdasarkan prinsip konvensional kepada nasabah yang membeli atau menjual produknya. Dengan demikian bunga merupakan harga yang harus dibayar pihak bank kepada nasabah untuk produk simpanan. Sementara disisi lain bunga juga merupakan harga yang harus dibayar oleh nasabah kepada bank untuk produk pinjaman. Lebih lanjut dijelas oleh Kasmir (2013 : 114), dalam kegiatan perbankan sehari-hari ada dua macam bunga yang diberikan kepada nasabahnya yaitu : 1) Bunga simpanan; Bunga simpanan merupakan bunga yang diberikan sebagai rangsangan atau balas jasa bagi nasabah yang menyimpan uangnya di bank. Bunga simpanan merupakan harga yang harus dibayar bank kepada nasabahya yaitu jasa giro, bunga tabungan, dan bunga deposito. 2) Bunga pinjaman; Bunga pinjaman merupakan bung yang diberikan kepada para peminjam atau harga yang harus dibayar oleh nasabah peminjam kepada bank.

Faktor-faktor yang mempengaruhi tingkat suku bunga menurut Kasmir (2013 : 115) adalah :1. Kebutuhan Dana, 2. Persaingan, 3. Kebijakan pemerintah, 4.Target laba yang diinginkan, 5. Jangka waktu, 6.Kualitas jaminan, 7.Reputasi perusahaan, 8. Produk yang kompetitif, 9. Hubungan baik, dan 10. Jaminan pihak ketiga.

Bonafiditas suatu perusahaan yang akan memperoleh kredit sangat menentukan tingkat suku bunga yang akan dibebankan nantinya, karena biasanya perusahaan yang bonafid kemungkinan risiko kredit macet di masa mendatang relatif kecil dan sebaliknya.

Untuk perhitungan bunga, khususnya bunga pinjaman (kredit) ada beberapa metode yang ditetapkan oleh perbankan, sesuai dengan keinginan nasabah sehingga ada pilihan-pilihan metode perhitungan. Hal ini ditegaskan oleh Fahmi (2014 : 64 - 70) bahwa bunga kredit yang diterapkan oleh suatu perbankan secara umum ada 4 (empat) yaitu : 1) Flate rate; Perhitungan bungan dengan flate rate, sifat perhitungannya tetap, dimana perhitungan terhadap bunga pinjaman adalah tetap yang otomatis pada jumlah bunga dan cicilan jumlahnya sama setiap bulannya, adapun saldo pokok pinjaman mengikuti perubahan jumlah yang ada saja atau semakin lama semakin berkurang. 2) Sliding rate; Dalam metode sliding rate, maka perhitungan jumlah bunga yang dibayar didasarkan kepada jumlah sisa pinjamannya. Oleh karena itu jumlah bunga yang dibayarnya setiap bulan semakin mengecil, sedangkan pokok pinjaman tetap. Diposisi ini nasabah menjadi lebih nyaman apabila jika dihubungkan dengan keinginan melunasikan pinjaman tersebut di pertengahan periode waktu. 3) Floating rate; Perhitungan floating rate adalah sifatnya mengambang atau penetapan tingkat suku bunganya ditetapkan berapa yang berlaku dipasaran khususnya di pasar uang (money market). Karena mengkuti kondisi yang berlaku di pasar uang jelas ini dipengaruhi oleh kondisi ekonomi makro baik oleh pasar domestik, regional maupun internasional dan juga tidak dapat dilepaskan dari berbagai permainan para spekulan di dalamnya yang semuanya berperan membentuk garis pasar uang tersebut. 4) Discounted rate; Discounted rate adalah kebijakan yang ditetapkan oleh perbankan pada kondisi dan situasi tertentu dengan alasan yang didasarkan karena faktor-faktor tertentu atau sesuatu dimana perbankan mempunyai keinginan untuk memberikan discounted rate pada debitur yang bersangkutan.

\section{Pelayanan}

Setiap produk memerlukan cara penganan pemasaran yang profesional sehingga memerlukan sumber daya di dalam pelayanan. Sumber daya manusia yang berkualitas tentu berkorelasi langsung dengan kualitas pelayanan. Menurut Goetsh dan Davis (Tjiptono, 2002:51) Kualitas adalah suatu kondisi dinamis yang berhubungan dengan produk, jasa, manusia, proses, dan lingkungan yang memenuhi atau melebihi harapan.

Pelayanan yang diharapkan oleh nasabah bank adalah pelayanan yang sesuai dengan harapan (ekspektasi) mereka. Apabila pelayanan tidak sesuai dengan yang diinginkan maka besar kemungkinan terdapat masalah di dalam pelayanan tersebut.

Untuk mengukur kualitas pelayanan, maka dapat dilihat dari beberapa aspek sebagaimana yang dikemukakan oleh Lupiyoadi dan Hamdani (2011:182), adalah sebagai berikut : 1) Bukti Fisik (Tangible), 2) Keandalan (Reliability), 3) Daya Tanggap (Responsiveness), 4) Jaminan (Assurance), dan 5) Empati (Empathy).

\section{Metode Penelitian}

Metode penelitian ini menggunakan metode penelitian deskriptif kualitatif. Data diproleh melalui proses wawancara dan dokumentasi, selanjutnya data diolah yang sampai pada penarikan suatu kesimpulan. Penelitian ini dilaksanakan di Kantor BNICabang sintang, dengan menetapkan beberapa informan yang dianggap dapat memberikan data dan informasi terkait fokus 
penelitian. Adapun yang menjadi informan atau subjek penelitian ini, yaitu : 1) Branch Manager BNI Cabang Sintang, 2) Pemimpin bidang pemasaran, 3) Staf pemasaran dan 4) Nasabah.

\section{HASIL PENELITIAN DAN PEMBAHASAN}

BNI Griya merupakan salah satu kredit konsumtif yang diperuntukan bagi masyarakat untuk membeli rumah, merenovasi rumah (termasuk ruko, rusun, rukan, kios, apartemen, kondominium, rumah peristirahatan / villa dan sejenisnya) dan membeli tanah kavling. Kemudahan dan Benefit yang dapat diperoleh dari produk BNI Griya antara lain 1) Proses cepat dan syarat mudah, 2) Bunga yang kompetitif, 3) Plafon kredit hingga 5 miliar, dan 6) Jangka waktu fleksibel, 7) Pre Approval kartu kredit dan bebas iuran tahunan untuk realisasi kredit Rp. 100 juta keatas. Minat nasabah atas suatu produk perbankan tidak terlepas dari daya tarik layananan dan produk yang ditawarkan oleh lembaga perbankan.

Upaya untuk meningkatkan minat konsumen terhadap suatu produk yang dihasilkan oleh perusahaan memerlukan strategi dan pengelolaan yang baik. Beberapa aspek yang berkaitan dengan pengembangan organisasi memerlukan analisis-analisis dan eksekusi dari keputusan tersebut.Upaya-upaya yang dilakukan pimpinan harus mempertimbangkan kondisi lingkungan bisnis yang berubah secara dinamis.

Segmentasi untuk produk BNI Griya adalah para pegawai, baik pegawai negeri maupun pegawai swasta yang berkeinginan untuk memiliki rumah tempat tinggal. BNI Griya merupakan produk kredit yang disediakan oleh BNI kepada nasabah khusus untuk tujuan kredit konsumtif berupa kredit kepemilikan rumah dan renovasi bangunan rumah. Selain itu BNI Griya juga melayani kredit selain untuk tujuan pembelian atau pembelian rumah, yaitu kredit multi guna. Kredit multi guna adalah kredit yang disediakan oleh perbankan untuk melayani kepentingan nasabah untuk membeli barang maupun jasa.

Kredit BNI griya merupakan kredit yang memerlukan agunan atau barang jaminan berupa aset milik debitur yang bersifat likuid atau mudah diuangkan seperti sertifikat deposito, sertifikat tanah, dan BPKB kendaraan. Penilaian barang jaminan dilakukan oleh bagian analis kredit. Barang yang dijadikan harus termasuk kategori barangbarang yang mudah dilelang atau dijual untuk diuangkan. Dengan demikian segmen untuk produk
BNI Griya juga digolongkan kepada pihak yang memiliki jaminan.

Produk jasa perbankan baik tabungan maupun kredit ditetapkan oleh lembanga bank atas dasar kondisi pasar yang ada. Pada suatu pasar yang terdiri dari berbagai latar belakang status sosial, ekonomi, pendididikan, profesi dan jenis kelamin masyarakat, akan mempengaruhi minat yang berbeda terhadap suatu produk barang maupun jasa yang ditawarkan lembaga perbankan. Penawaran suatu produk akan menimbulkan suatu permintaan. Permintaan timbul karena ada kepentingan dari konsumen sehingga menimbulkan minat untuk memiliki produk. Untuk mendapatkan produk yang ditawarkan oleh perbankan maka nasabah/debitur harus membeli produk tersebut dengan cara memberikan sejumlah uang berupa biaya administrasi serta balas jasa atas kredit yang diambil.

Penawaran sebuah produk memerlukan berbagai cara untuk menarik minat dari calon konsumen. Promosi yang dilakukan sangat berguna untuk memperkenalkan produk yang berisikan keunggulan-keuanggulan, karakteristik produk dan persyaratan yang harus dipenuhi oleh konsumen untuk mendapatkan produk yang diinginkannya. Untuk menghasilkan kegiatan promosi yang efektif dan efisien tentu harus ditentukan pula langkahlangkah strategis promosi. Oleh karena itu harus dilakukan pertimbangan dan kajian mengenai promosi yang tepat untuk dilakukan perbankan.

Setiap produk perbankan yang ada dilakukan promosi dalam rangka memperkenalkan produk kepada masyarakat. Promosi yang dilakukan melalui tenaga pemasaran yang dapat memberikan penjelasan kepada nasabah. Oleh karena itu tenaga pemasar harus sangat memahami produk yang akan dijelaskan ke nasabah. Produk BNI Griya merupakan produk spesifik untuk investasi properti dan multi guna dengan tingkat suku bunga bersaing.

Promosi yang dilakukan oleh staf marketing juga menggunakan brosur sehingga lebih memudahkan menjelaskan ke calon debitur karena ada panduan yang digunakan. Brosur tersebut berisikan mengenai kategori tingkat suku bunga pinjaman, jangka waktu yang dapat dipilih, besarnya flatpon pinjaman, serta kebutuhan nasabah yang dapat dipenuhi dengan jenis produk pinjaman Griya. Ada banyak pilihan mengenai tingkat suku bunga yang dipilih tergantung kepada jangka waktu yang dipilih nasabah. 
Suku bunga perbankan untuk setiap produk tentu berbeda sesuai dengan karakteristik dan tujuan dari produk masing-masing. Begitu juga tingkat suku bunga dipengaruhi oleh biaya transaksi dan premi resiko. Tingkat suku bunga akan mempengaruhi permintaan nasabah akan produk perbankan yang ditawarkan, selain itu jaminan (asurance) juga akan menentukan tingkat suku bunga yang ditetapkan.

Tingkat suku bunga bank, khususnya produk BNI Griya bervariasi dari tahun ke tahun. Variasi suku bunga ini dipengaruhi oleh jangka waktu, standar bunga Bank Indonesia, tingkat bunga pesaing dan laba yang diinginkan. Hal lain yang mempengaruhi tingkat suku bunga juga berkaitan dengan jenis dan tujuan pinjaman.

Tingkat suku bunga BNI Griya dapat menjadi daya tarik atau menarik minat nasabah untuk melakukan pinjaman/kredit. Tingkat suku bunga yang rendah terutama pada tahun pertama, kedua, ataupun tahun ketiga. Apabila tingkat suku bunga tersebut dihitung perbulan maka dibawah 1 $\%$ perbulannya atau berada pada kisaran $0,5 \%$ sampai $0,6 \%$ per bulannya. Hal ini tentunya dapat menumbuhkan minat nasabah untuk melakukan kredit mengingat tingkat suku bunga bank lainnya lebih besar dari tingkat suku bunga tersebut. Tingkat suku bunga yang rendah akan menumbuhkan minat nasabah untuk melakukan kredit perumahan, renovasi dan sebagainya. Keuggulan kredit ini juga dapat diangsur dalam jangka waktu yang lama yaitu dapat mencapai 20 tahun waktu pembayarannya.

Minat untuk memilih produk BNI Griya karena tingkat suku bunga lebih rendah dari bank lain. Tingkat suku bunga yang rendah dapat menguntungkan debitur karena dapat mengurangi beban biaya bunga yang harus disetor sehingga angsuran pokok dapat lebih banyak yang selanjutnya dapat menyelesaikan kredit lebih cepat dan sesuai dengan kemampuan keuangan untuk membayar per bulannya.

Pelayanan perbankan BNI cabang sintang dilakukan oleh beberapa staf yang menanggani tugas masing-masing sesuai dengan yang diberikan oleh atasan. Pelayanan untuk kredit dilakukan oleh kepala bagian kredit bersama analis kredit dan staf marketing. Tugas kepala bagian kredit melakukan koordinasi dan memimpin bagian perkreditan. Bagian perkreditan melakukan pengarahan, bimbingan, dan membuat program kerja dan melakukan monitoring serta evaluasi kerja. Sementara itu staf analis kredit melakukan pekerjaan menganalisa kredit yang diajukan oleh nasabah. Melakukan interview (wawancara), pemeriksaan/verifikasi berkas pengajuan pinjaman. Mencocokan antara data dan informasi melalui wawancara. Menganalisis jumlah pengajuan pinjamn, jangka waktu, tujuan kredit dan kelayakan jaminan pinjaman.

Pihak analis kredit dibantu oleh staf administrasi kredit untuk mempersiapkan suratsurat perjanjian/akad kredit, melakukan pengelompokan, dan penyimpanan berkas. Pelayanan kredit memerlukan waktu yang berbeda antara nasabah yang satu dengan yang lainnya sehingga perlu juga dilakukan penjadwalan kredit. Proses kredit dijelaskan oleh bagian analis kredit kepada nasabah sehingga nasabah dapat mengerti dan memahami langkah-langkah yang harus dilalui mulai dari pengajuan kredit sampai kredit tersebut dapat dicairkan.

Tata cara kredit memenuhi beberapa langkah berikut : 1) Permohon kredit oleh nasabah, 2) wawancara pendahuluan, 3) Pengisian formulir, 4) Penyiapan dokumen, 5) Survei, 6) wawancara kedua, 7) keputusan kredit, 8) pencairan/realisasi. Proses dan tahapan pelaksanaan kredit sudah dilaksanakan sesuai dengan prosedur BNI. Sumber manusia sudah memenuhi kualifikasi sesuai bidang masing-masing.

\section{KESIMPULAN DAN SARAN}

Produk BNI Griya dikhususkan untuk kalangan pegawai, baik pegawai negeri maupun pegawai swasta. Tujuan ditetapkannya segmen adalah supaya pihak bank lebih mudah untuk menganalis pinjaman nasabah karena adanya kepastian sumber penghasilan untuk membayar pinjaman. Upaya yang dilakukan untuk mengenalkan produk ke masyarakat maka dilakukan promosi Produk BNI Griya.Promosi yang dilakukan dengan cara mendatangi langsung instansi pemerintah atau swasta dengan melakukan penawaran produk dan juga menggunakan brosur untuk mengefektifkan kegiatan promosi.

Tingkat suku bunga BNI Griya bervariasi yaitu berkisar antara 7,75\% - 12\% dengan sistem Flate rate (bunga tetap) dengan jangka waktu 1-5 tahun, untuk tahun selanjutnya bunga disesuaikan dengan tingkat bunga pasar (floating rate).

Pelayanan perbankan BNI sudah sudah dilakukan dengan baik.Pengawai sudah melaksanakan tugas dan tanggung jawab sesuai dengan tugas dan fungsi yang dimiliki. 
46. Fokus, Volume 19, Nomor 1, Maret 2021, hlm. 40 - 46

\section{DAFTAR PUSTAKA}

Alma, Buchari. 2007. Manajemen Pemasaran \& Pemasaran Jasa. Bandung : CV. Alfabeta.

Fahmi, Irham. 2014. Manajemen Perkreditan. Bandung : Alfabeta.

Kasmir. 2013. Dasar-Dasar Perbankan. Jakarta : Rajawali Pers.

Kasmir. 2014. Bank dan Lembaga Keuangan Lainnya. Jakarta : Raja grafindo Persada. Kotler Philip. 2001. PrinsipPrinsipPemasaran. EdisiDelapan, Jilid I dn II.Jakarta :Erlangga.

2010. Manajemen Pemasaran. Edisi tiga belas Bahasa Indonesia. Jilid 1 dan 2.Jakarta : Erlangga.
Rambat, Lupiyoadi dan A. Hamdani, 2011. Manajemen Pemasaran Jasa Edisi 2, Jakarta: Salemba Empat.

Rangkuti, Freddy.2009. StrategiPromosi yang KreatifdanAnalisisKasus Integrated Marketing Communication.Jakarta :PT. Gramedia Pustaka Utama.

Saladin, Djaslim, 2006. Manajemen Pemasaran. Edisi Keempat, Bandung : Linda Karya.

Sunyoto, Danang. 2014. Studi Kelayakan Bisnis. Yogyakarta : CAPS.

Tjiptono. 2002. StrategiPemasaran. Yogyakarta : ANDI. 